\begin{tabular}{|l|l|l|}
\hline \multicolumn{2}{|c|}{ PublisherInfo } \\
\hline \hline PublisherName & $:$ & BioMed Central \\
\hline \hline PublisherLocation & $:$ & London \\
\hline \hline PublisherImprintName & $:$ & BioMed Central \\
\hline \hline
\end{tabular}

\title{
Healthtouch Drug Database
}

\begin{tabular}{|l|l|l||}
\hline \multicolumn{2}{|c||}{ ArticleInfo } \\
\hline \hline ArticleID & $:$ & 4276 \\
\hline \hline ArticleDOI & $:$ & $10.1186 /$ ccf-2000-webreport1183 \\
\hline \hline ArticleCitationID & $:$ & webreport1183 \\
\hline \hline ArticleSequenceNumber & $:$ & 17 \\
\hline \hline ArticleCategory & $:$ & Web report \\
\hline \hline ArticleFirstPage & $:$ & 1 \\
\hline \hline ArticleLastPage & $:$ & 3 \\
\hline \hline & & RegistrationDate : 2000-11-2 \\
\hline ArticleHistory & $:$ & OnlineDate \\
\hline ArticleCopyright & $:$ & Current Science Ltd2000-11-2 \\
\hline \hline ArticleGrants & $:$ & \\
\hline \hline ArticleContext & $:$ & 1305444 \\
\hline \hline
\end{tabular}




\section{Overview}

The database is taken from the US Pharmacopeia, and provides information on more than 10,000 prescription and 'over the counter' drugs. The database provides the reader with a wealth of information on the drug they are interested in. This consists of a detailed description of the drug, including: things to note before taking/administering the drug (eg drugs that should not be taken in combination, whether it's safe to breast feed/to take when pregnant, other medical problems that may affect the effectiveness of the drug); dosage advice; and side effects.

Other services available on this site include a health information link which consists of an alphabetically arranged list of ailments and diseases. You can click on the disease of your choice to find out more information. There is also a health resource directory, listing links to healthcare organisations.

\section{Content}

The site is easy to navigate even for beginners. The large number of drugs listed and the plethora of information given makes this a useful resource. However, the site is mainly aimed at the general public rather than healthcare professionals. The site would benefit from a link taking the user from the disease information to related drugs.

\section{Other comments}

Each of the drugs pages show different last update dates and it is difficult to tell when the site as a whole was last updated. 


\section{References}

1. Healthtouch Online. [http://www.healthtouch.com/level1/p_dri.htm]

This PDF file was created after publication. 